\title{
"Modelling of capital structure in relation to business performance maximization"
}

\begin{tabular}{|c|c|}
\hline AUTHORS & $\begin{array}{l}\text { Jarmila Horvathova (D https://orcid.org/0000-0003-3388-8635 } \\
\mathbb{R} \text { http://www.researcherid.com/rid/D-2360-2018 } \\
\text { Martina Mokrisova (D https://orcid.org/0000-0001-9473-2429 } \\
\mathbb{R} \text { http://www.researcherid.com/rid/D-2350-2018 } \\
\text { Lucia Dancisinova } \mathbb{D} \text { https://orcid.org/0000-0002-5004-0460 } \\
\mathbb{R} \text { http://www.researcherid.com/rid/C-7505-2018 }\end{array}$ \\
\hline ARTICLE INFO & $\begin{array}{l}\text { Jarmila Horvathova, Martina Mokrisova and Lucia Dancisinova (2018). Modelling } \\
\text { of capital structure in relation to business performance maximization. Investment } \\
\text { Management and Financial Innovations, 15(2), 292-304. } \\
\text { doi:10.21511/imfi.15(2).2018.26 }\end{array}$ \\
\hline DOI & http://dx.doi.org/10.21511/imfi.15(2).2018.26 \\
\hline RELEASED ON & Tuesday, 19 June 2018 \\
\hline RECEIVED ON & Thursday, 26 April 2018 \\
\hline ACCEPTED ON & Friday, 25 May 2018 \\
\hline LICENSE & $\begin{array}{l}(c) \text { EY } \\
\text { This work is licensed under a Creative Commons Attribution } 4.0 \text { International } \\
\text { License }\end{array}$ \\
\hline JOURNAL & "Investment Management and Financial Innovations" \\
\hline ISSN PRINT & $1810-4967$ \\
\hline ISSN ONLINE & $1812-9358$ \\
\hline PUBLISHER & LLC "Consulting Publishing Company "Business Perspectives" \\
\hline FOUNDER & LLC "Consulting Publishing Company "Business Perspectives" \\
\hline
\end{tabular}

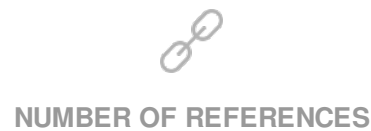

38

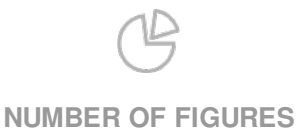

6
韺

NUMBER OF TABLES

2

(C) The author(s) 2023. This publication is an open access article. 


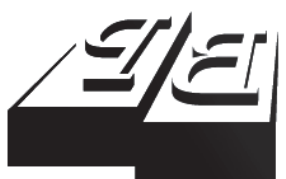

BUSINESS PERSPECTIVES

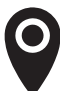

LLC "CPC "Business Perspectives" Hryhorii Skovoroda lane, 10, Sumy, 40022, Ukraine

www.businessperspectives.org

Received on: $26^{\text {th }}$ of April, 2018 Accepted on: $25^{\text {th }}$ of May, 2018

(C) Jarmila Horvathova, Martina Mokrisova, Lucia Dancisinova, 2018

Jarmila Horvathova, Ing. CSc., Assistant Professor, Faculty of Management, University of Prešov, Slovakia.

Martina Mokrisova, Ing. Ph.D., Assistant Professor, Faculty of Management, University of Prešov, Slovakia.

Lucia Dancisinova, Mgr. Ph.D., Assistant Professor, Faculty of Management, University of Prešov, Slovakia.

\section{(ㄷ) (i)}

This is an Open Access article, distributed under the terms of the Creative Commons Attribution 4.0 International license, which permits unrestricted re-use, distribution, and reproduction in any medium provided the original work is properly cited.
Jarmila Horvathova (Slovakia), Martina Mokrisova (Slovakia),

Lucia Dancisinova (Slovakia)

\section{MODELLING OF CAPITAL STRUCTURE IN RELATION TO BUSINESS PERFORMANCE MAXIMIZATION}

\begin{abstract}
The aim of the article was to find out the optimal capital structure of the companies in relation to their maximum performance. To reach this aim, the data of the companies operating in the field of heat industry of the Slovak Republic were used. As the first method, a correlation matrix was applied. It was found out that there is statistically significant relationship between capital structure indicators and performance of the companies. Due to the lack of data in time series, the authors were not able to apply multiple regression model to assess the impact of these indicators on performance. Therefore, a method of modelling was used to analyze the impact of the change in capital structure on performance. Modelling was based on the principle of a gradual change in the capital structure in favor of debt. By the increase in debt, it was confirmed that there was a change in the values of selected indicators. In the course of analysis, it was confirmed that the value of EVA equity increased with the rising indebtedness by which the proposition I of the modified MM theory was supported. The performance expressed by EVA entity indicator is at its minimum when the capital structure is 90:10 in favor of equity. By increasing the debt, EVA entity rises. Based on these results, it can be stated that the performance of selected companies increases when the share of debt also rises, even when taking into account the rising financial risks.
\end{abstract}

Keywords

JEL Classification business, capital structure, cost of equity, debt, equity, performance

G32, C53, M21

\section{INTRODUCTION}

Company's performance is the precondition of its success and competitiveness. The measurement and evaluation of performance is a current problem. The performance of a company is determined by various factors such as the capital structure used by a company for its business activities and, especially, the cost of its capital. The development and present state of the capital structure of Slovak companies do not depend only on individual conditions in each company, such as the structure of assets, its owners, productivity of business activity, but also on the external factors of business environment, which are determined by macroeconomic, legislative and institutional conditions.

In accordance with the abovementioned, we formulated the following research question: "Is the performance of a company influenced by the change of its capital structure?" 


\section{LITERATURE REVIEW}

The issue of optimal capital structure represents one of important, yet still unsolved areas of modern theory of company finances. It is a complex problem, which includes not only the determination of suitable proportion of debt, but also of its structure with respect to the length of maturity of its individual components. In literature, it is possible to encounter two approaches to the determination of financial and capital structure. Synek et al. (2003) consider these two terms to be equal and claim that capital, as well as financial structure of a company represent sources of company's assets. Various authors (Bartošová, 2005; Sivák \& Mikócziová, 2009; Valach, 2001; Vlachynský et al., 2002; Jánošová, 2008) believe that the capital structure in comparison with a financial one is a narrower term and characterizes the structure of long-term capital, which is used to finance the company's long-term assets. According to a different definition, this structure informs users about the type of capital, terms of commitment of a company's capital, as well as the stability of a company. It provides the information whether a company uses this capital optimally in terms of indebtedness and commitment (Sedláček, 2009). According to Jánošová (2008), company's capital structure is quantified by a number of indicators. The most frequently used ones are the following: "Debt Ratio, Equity Ratio, Indebtedness Ratio, Equity to Debt Ratio, Interest Coverage Ratio (key performance indicator, risk driver of capital structure), Interest Expense, Equity to Fixed Assets Ratio, Long-term Capital to Fixed Assets Ratio, Financial Leverage, and others" (Horváthová \& Mokrišová, 2017).

Several professionals in the field of financial management have dealt with the idea of the optimal capital structure. Numerous theories have been elaborated (static and dynamic theories of capital structure) and many views and opinions have been published on the issue of financial sources of company's activities (Závarská, 2012). Since the birth of the original Modigliani and Miller (1958) book, the problem of capital structure and its optimization has been discussed intensively among professionals. It stimulated the creation of a modern theory of company finances. One of the frequently discussed questions was the one about the propor- tion of equity and debt to maximize the performance of a company and its value. However, many attempts to explain the capital structure failed, or did not come to any satisfactory conclusion. That is why the issue of the optimization of the capital structure, as well as of the right choice of financing, has still been a topical problem. Generally, the theories of capital structure can be divided into two fundamental groups. The first one comprises static and the second one dynamic theories of capital structure. Static theories deal with the consideration of an optimal indebtedness and look for an answer to the question whether an optimal indebtedness exists and, if yes, then, how to define it, based on which criteria and from which point of view (owners, managers or creditors). This group includes the classic theory (the approach in terms of earnings after taxes, and net operating profit after tax), the traditional approach (theory of U-curve), the theory of Miller and Modigliani (MM theory) and the trade-off model. On the other hand, representatives of dynamic theories claim that there is no homogeneous methodology to set an optimal capital structure because of the specific conditions in each company. Among dynamic theories, there are the pecking order theory and signalling model (Závarská, 2012). The theories, which can be considered the best to describe the financial behavior of companies at present, are the trade-off model and the pecking order theory. except for the pecking order theory, these models consider such a capital structure to be optimal when the market value of the equity of a company is maximized, while retaining the structure of assets. In the course of time, it appeared that this aim was possible to equate with the maximization of market value of a company, or minimization of capital costs (Sivák \& Mikócziová, 2009). Optimal capital structure is then possible to be defined from the point of view of two basic approaches (Sivák \& Mikócziová, 2009; Vlachynský et al., 2002; Valach, 2001). According to the first of them, the optimal capital structure represents such a composition of long-term capital when the weighted average capital cost is minimal. Consequently, with such a capital structure, the total value of a company is maximal. In case of the first approach, then the criterion of optimization is "to maximize the market value of a company" (Vlachynský et al., 2002, p. 110). According to the second approach, the optimal capital structure is reached when the ad- 
vantages arising from the increasing proportion of debt are equal to the marginal costs of financial difficulties connected with the rise of debt. In case of the second approach, the criterion of optimization is "to minimize the costs connected with acquiring and fixing the debt of a business entity" (Vlachynský et al., 2002, p. 110).

Presented models of capital structure optimization are not universally applicable, but some general formulations concerning successful management of a company's capital structure can be inferred. Modigliani and Miller (1958) proved that "in an emerging market, the company's capital structure is irrelevant". However, this model was expanded by other models, which took into account the imperfections of capital market. Among them, there is also the trade-off model, which defines the optimal capital structure based on the analysis of how the advantages and disadvantages of debt influence the market value of a company. Then, the optimal proportion of debt is such when "marginal advantages and disadvantages of increasing the debt are the same". The advantages of rising debt are increased tax savings on interest and lower agency cost of equity, the disadvantages are the higher risk of financial difficulties and higher agency cost of debt (Sivák \& Mikócziová, 2009).

However, from a theoretical point of view, the classic theory and theory of Inka and Ivan Neumaier are the most appropriate theories of optimal capital structure, since both offer the opportunity to empirically determine the capital structure of a company (Hrdý \& Horová, 2007). According to Inka and Ivan Neumaier (1996), proponents of the classic theory promote the idea of the existence of optimal capital structure. They state: "It is possible to agree with them that the optimal capital structure exists, but we cannot accept that it is at a point where the cost of capital is minimal" (Neumaierová \& Neumaier, 1996, p. 52). Based on their research of optimal indebtedness, it is at the point when the return on equity is maximal.

Capital structure is influenced by several factors, such as capital costs, financial difficulties costs, structure of company's, assets impact of inflation, influence of financial security and variance, an effort to keep the ownership control of a company, or financial market situation (Vlachynský et al.,
1999). One of the most important factors, which influences the capital structure, is the cost of capital, especially of equity and debt (Růčková, 2008; Horváthová \& Mokrišová, 2017). There are several methods in theory how to set the cost of capital, while in this paper, we applied primarily the valuation of the cost of equity by CAPM model with the acceptance of external risks (Damodaran, 2014; Horváthová \& Mokrišová, 2017). The cost of the total capital was calculated as weighted average capital cost. These models use for calculation the quantification of various risks, which enter the capital valuation. That is why for determining the optimal capital structure of a company it is necessary to quantify also the risks and analyze the influence of risks arising from the capital structure on the valuation of capital and the performance of a company.

As a general rule, the cost of equity is higher than the cost of debt. It is because the risk of an owner is higher than the risk of a creditor and also because the share of profit of owners is paid after taxation, while interest is a part of costs and lowers the basis for the tax paid by a company. The increase of debt share on the total capital of a company (the use of financial leverage) shows the tendency to lower the weighted average capital cost of a company used to gain and fix the capital. On the other hand, the risk of insolvency of a company and other financial problems increases and can even lead to its liquidation. The increase of (cheaper) debt in the financial structure of a company can therefore positively influence the level of economic profit. With the rise of indebtedness, the risk of bankruptcy in case of unforeseen circumstances increases. This risk is gradually reflected in the expectations of creditors. They start to ask the increase in the return on investment as a compensation for the risk taken. The aim of the company's owner therefore is to optimize the capital structure in terms of lowering the weighted average capital cost.

In case we want to rely on some author's research bases when studying the relationship between the capital structure and performance, we can conclude that there exists a relationship between the capital structure and performance. Based on the Sheikh's (2013) research studies, we can state that there is an indirectly proportional relationship between the capital structure and return on assets. 
This indirectly proportional relationship is justified by the fact that the amount of agent costs leads firms to higher usage of debt in their capital structure. However, this increase in debt consequently negatively affects the work of managers, especially in case they need to solve operational tasks and issues. This problem is related to the fact that by increasing the debt, the performance and results of a firm are affected. According to Myers, Majluf (1984) and Bevan, Danbolt (2002), profitable firms are less dependent on debt than those that are not profitable. According to Neumaier, Neumaierová (2002), profitable firms operate predominantly with equity and this way, they achieve higher performance. However, according to Zeitun, Tian (2014), the firms that show high growth show also high share of debt in their capital structure. The study of Krishnan and Mayer (1997) talks about negative impact of indebtedness ratio on the return on equity. Gleason, Mathur and Mathur (2000) found out in their study that there exists significant and strong impact of capital structure on performance.

In our realized research, we will try to confirm or reject the results of published studies.

According to Wagner (2009), performance generally means the characteristic, which describes the way or course of how the examined subject performs certain activity based on similarity with referential means of performance of this activity (Horváthová \& Mokrišová, 2017). According to Fibírová and Šoljaková (2005), the term performance is used in connection with delimitation of the nature of the existence of a company in a market environment, its success and ability to survive in the future (Horváthová \& Mokrišová, 2017). Sedláček et al. (2012) add that this term is linked to productivity, i.e. with the realized output of a given company and the performance is relatively easily calculated and further analyzed. Veber (2004) defines performance as a general amount of an individual's effort and gives into mutual relationship the contributions, or benefits, with used sources. Similar definition of performance is articulated by the European Foundation for Quality Management (EFQM), which defines it as the level of reached outcomes by individuals, groups or processes (EFQM, 1999; Horváthová \& Mokrišová, 2017).
The term "company performance" also can be defined from the points of view of several authors. Souček (2010, p. 105) characterizes company performance as "the ability of the subject (company, firm, etc.) to produce, in a given period, a sum of goods and services and the company, which wants to continually prevail, must have at least twice the performance as is the average in a given sector". Similar approach to the definition of the company performance is held also by Suchánek et al. (2013), according to which company performance can be viewed in connection with productivity of the company, which in its essence means the output reached by the company as a result of the production process, which is implemented. Other definition describes company performance as an ability of a company to transform production factors into resulting products and services (Johnson \& Kevan, 2000). Neumaierová and Neumaier (2002), Frost (2005), Šulák and Vacík (2005) are the authors who consider productivity as an ability of a company to obtain the best return on investment invested into its business activities.

Based on theoretical assumptions that have been processed, we can conclude that the problem of capital structure optimization in relation to maximization of business performance is highly topical. The question to be resolved, which is in the centre of attention of a number of experts, is whether the increasing debt in capital structure affects the performance of a company in a positive or negative way. A problem, which is equally interesting, is the answer to a question whether there is an optimal capital structure and whether it is related to the minimum cost of capital, or the maximum market value of the company or whether it is achieved regardless of these aspects.

\section{MATERIALS AND METHODS}

The research aimed at the optimization of capital structure used the sample of 30 businesses - the heat distributors (called TP in the paper) operating in Slovakia. Those are local systems of central heating supply, which show signs of network industries and, in individual localities, they function on the principle of natural monopoly. High input costs are characteristic for them. In con- 
nection with the European Union regulations in the field of energy efficiency and with gradual weatherization of buildings in recent years, the heat consumption has decreased. It is the reason of increase in the proportion of fixed costs of unit price of heat. To secure their competitiveness, the companies have to look for new customers, which is very difficult today (AMO SR, 2013; MHSR, 2014). For the purpose of the analysis, financial data of the companies published in the Register of Financial Statements (RUZ, 2017) were used. In terms of input analysis of capital structure of the analyzed sample, these companies are financed especially by the equity, which is indicated also by interest coverage ratio. Their average debt ratio is at the level of $56 \%$, while current indebtedness prevails. On average, the companies' equity represents $44 \%$. The analyzed sample of companies has enough long-term capital.

In accordance with the research question, we proposed the following research aim: "To set the optimal capital structure of the analyzed sample of companies in terms of maximization of performance and minimization of the cost of capital.

To calculate the performance of a company, EVA indicator in the modifications of EVA equity and EVA entity was used. At present, this indicator is the most famous and the most used indicator of performance calculation. EVA model has been known since 1980. Representatives of the company Stern Stewart \& Co., Joel M. Stern and G. Bennett Stewart III, are the authors of the model. The main function of EVA model is the measurement of the economic profit of a company.

We calculate $E V A$ equity based on the formula (Neumaierová \& Neumaier, 2002; Harumová et al., 2008):

$$
E V A=\left(R O E-r_{e}\right) \cdot E,
$$

where $R O E$ is the return on equity, $r_{e}$ is cost of equity, $E$ is equity.

We calculate EVA entity based on the following relationship (Harumová et al., 2008; Mařík \& Maříková, 2005):

$$
E V A=N O P A T-W A C C \cdot N O A,
$$

where NOPAT is net operating profit after tax, $W A C C$ is weighted average capital cost, NOA is net operating assets.

We performed the analysis of the impact of capital structure on the performance of a company by applying a relative indicator $E V A$ (Spread), which is calculated by the formula:

$$
\frac{E V A}{E}=R O E-r_{e} \text {. }
$$

For the quantification of the cost of equity, we chose the CAPM model, which enabled us to capture the impact of external risks on the performance following the change in the company's capital structure. Based on the theoretical foundations in the area of application of the CAPM model with acceptation of given risks, the CAPM model modified by Damodaran (2014) is used today for the valuation of the cost of equity. It is a model with the acceptance of the country risk premium (CRP). This model is based on the country's credit risk and rating, which are, then, analyzed from the point of view of an investor. the cost of equity, according to Damodaran (2014), can be calculated based on the formula:

$$
r_{e}=r_{f U S A}+\beta \cdot E R P_{U S A}+C R P
$$

where $r_{e}$ is cost of equity, $r_{f U S A}$ is risk-free rate of return of the USA, $E R P_{U S A}$ is equity risk premium of the USA, CRP is country risk premium.

We applied a correlation matrix to analyze the relationship between performance of the selected sample of businesses and the capital structure indicators. The inputs of the correlation matrix were as follows: Debt Ratio - DR, Equity Ratio - ER, Indebtedness Ratio - IR, Equity to Debt Ratio - EDR, Interest Coverage Ratio - ICR, Interest Expense - IE, Equity to Fixed Assets Ratio - EFAR, Long-term Capital to Fixed Assets Ratio - LCFAR, Financial Leverage - FL, relative EVA - EVAROS.

The correlation matrix, which is used to assess correlation between paired variables, is understood as a symmetric matrix

$$
R=\left(\rho_{i j}\right)_{i, j=1, \ldots, n},
$$

where $\rho_{i i}=1, \quad i=1, \ldots, n, \quad \rho_{i j}=\rho\left(X_{i}, X_{j}\right)$, $i, j=1, \ldots, n$, is the correlation coefficient of ran- 
dom variables. $X_{i}, X_{j}$ take values from the interval $\langle-1,1\rangle$. The numerical value indicates strength - tightness of a linear relationship, and the sign determines the direction of the relationship - direct, indirect. The value close to 1 represents a strong direct linear relationship between variables and value close to -1 represents a strong indirect linear relationship between variables. If the value of a correlation coefficient is close to zero, it does not mean that there is no relationship between variables, but the relationship can be nonlinear (Hudec et al., 2007).

The correlation matrix consists of calculated values of the correlation coefficients among all possible pairs of variables. Its formula can be expressed as follows (Hudec et al., 2007):

$$
R=\left(\begin{array}{cccc}
1 & \rho_{12} & \cdots & \rho_{1 n} \\
\rho_{21} & 1 & \cdots & \rho_{2 n} \\
\vdots & \vdots & \vdots & \vdots \\
\rho_{n 1} & \rho_{n 2} & \cdots & 1
\end{array}\right) .
$$

The correlation matrix was processed with the use of software Statistica. This software marked the correlations, in which $p$-values were less than significance level $\alpha=0.05$. To interpret the correlation coefficient, we used Cohen's (1998) scale, according to which the absolute value of correlation coefficient above 1 is interpreted as strong correlation, the value of correlation coefficient from 0.3 to 0.5 expresses moderate correlation and the value of a correlation coefficient from 0.1 to 0.3 means weak correlation.

To analyze the impact of the change in capital structure on the selected performance indicators, we used modelling based on the proportional change of equity and debt and on capturing of the impact of this change on the analyzed sample of companies. For the wider scope of the research, we present in the paper the results, which are connected with the application of the CAPM model. In modelling, we proceeded from the principles of classic models of capital structure optimization. The traditional model was one of them, which presupposes that there is an optimal capital structure with the debt ratio lower than the possible maximum for each company. This model proceeds from the assumption that with increasing indebtedness, the risk of financial difficulties also rises and, consequently, the expected rate of return on equity and, later, the yield of the desired rate of debt starts to progressively grow. Still, the weighted average capital cost may be lower until the benefits of increasing the share of debt are lower than the disadvantages of rising cost of equity, as well as of debt. MM theory of Modigliani and Miller can be considered to be in opposition to the previous one, because they claim that the value of a company is independent of the company's capital structure. At the same time, they claim that the required rate of return on equity is equal to the rate of return linked to the operational risk as would be required by shareholders, if the company was financed solely by its equity, increased by a surcharge of financial risk due to the level of indebtedness of the company (proposition II of MM theory). However, in case of their modified model, they proved that the market value of a company increased with rising rate of indebtedness. In this paper, we accepted the presuppositions of the given models and the results of our research are presented in the next section.

\section{RESULTS AND DISCUSSION}

As a starting point of our modelling, it was necessary to quantify the performance of analysed companies. Resulting values of EVA equity and EVA entity are shown in Table 1. Based on these values, we can state that the highest value in the area of performance was reached by the company TP27 and the lowest one by the company TP3. From the analyzed sample of companies, fourteen companies are efficient and sixteen are inefficient. The average value of $E V A$ equity was EUR 935.000 and that of EVA entity was EUR 905,000. All the analyzed companies exs cept one, which was TP8, reached positive EBIT in the observed period. It was the presupposition for these companies to be evaluated as efficient. Based on this fact, it is possible to suppose that the negative value of EVA indicator is caused by the cost of capital, i.e. the companies which reached the negative value of $E V A$ indicator use the high cost of capital in their business activity. 
Table 1. Values of EVA equity and EVA entity (EUR)

Source: Authors.

\begin{tabular}{|c|c|c|c|c|c|c|c|}
\hline Business & EVA equity & EVA entity & Average & Business & EVA equity & EVA entity & Average \\
\hline TP27 & $1,036,979$ & $1,023,940$ & $1,030,459$ & TP30 & $-61,740$ & $-62,968$ & $-62,354$ \\
\hline TP18 & 654,216 & 706,389 & 680,303 & TP25 & $-64,732$ & $-66,135$ & $-65,433$ \\
\hline TP23 & 556,759 & 600,570 & 578,664 & TP13 & $-172,458$ & $-169,623$ & $-171,041$ \\
\hline TP26 & 398,896 & 411,237 & 405,067 & TP28 & $-379,508$ & $-383,981$ & $-381,744$ \\
\hline TP1 & 210,113 & 226,639 & 218,376 & TP16 & $-446,964$ & $-442,580$ & $-444,772$ \\
\hline TP12 & 196,537 & 217,763 & 207,150 & TP20 & $-521,766$ & $-564,858$ & $-543,312$ \\
\hline TP21 & 159,143 & 165,913 & 162,528 & TP22 & $-611,595$ & $-590,417$ & $-601,006$ \\
\hline TP19 & 158,564 & 154,163 & 156,364 & TP8 & $-886,852$ & $-850,575$ & $-868,714$ \\
\hline TP10 & 151,012 & 127,543 & 139,278 & TP15 & $-971,848$ & $-951,801$ & $-961,825$ \\
\hline TP9 & 81,454 & 130,796 & 106,125 & TP7 & $-1,655,464$ & $-1,637,673$ & $-1,646,569$ \\
\hline TP11 & 80,044 & 105,275 & 92,659 & TP2 & $-2,622,734$ & $-2,428,221$ & $-2,525,478$ \\
\hline TP29 & 86,088 & 84,536 & 85,312 & TP6 & $-2,684,476$ & $-2,594,321$ & $-2,639,398$ \\
\hline TP24 & 16,677 & 23,626 & 20,151 & TP5 & $-3,156,352$ & $-3,086,274$ & $-3,121,313$ \\
\hline TP14 & 12,340 & 18,433 & 15,387 & TP4 & $-6,738,880$ & $-6,580,559$ & $-6,659,720$ \\
\hline TP17 & $-58,278$ & $-49,625$ & $-53,951$ & TP3 & $-10,834,049$ & $-10,700,662$ & $-10,767,356$ \\
\hline
\end{tabular}

The first part of the research was to point out the results of correlation matrix (see Table 2). The correlation matrix confirmed statistically significant relationship between the indicator EVAROS and indicators debt ratio and equity ratio. In case of the indicator debt ratio, it is directly proportional relationship, on the other hand in case of the indicator equity ratio, it is indirectly proportional relationship. Based on the abovementioned, we can conclude that there is statistically significant relationship between the capital structure and per- formance. The correlation matrix also confirmed statistically significant relationship between the indicator interest expense and indicator EVAROS. This again confirms the relationship between performance of the company and its capital structure, even in relation to the costs associated with the capital structure of the company.

Then, we used modelling of selected performance indicators in relation to capital structure of a company.

Table 2. Correlation matrix

Source: Authors.

\begin{tabular}{|c|c|c|c|c|c|c|c|c|c|c|}
\hline Indicator & DR & ER & IR & EDR & ICR & IE & EFAR & LCFAR & FL & $\begin{array}{l}\text { EVA } \\
\text { ROS }\end{array}$ \\
\hline DR & $\begin{array}{c}1.0000 \\
p=-\end{array}$ & $\begin{array}{l}-1.0000 \\
p=0.00\end{array}$ & $\begin{array}{c}.4999 \\
p=.005\end{array}$ & $\begin{array}{c}-.7660 \\
p=.000\end{array}$ & $\begin{array}{l}-.2548 \\
p=.174\end{array}$ & $\begin{array}{c}.3015 \\
p=.105\end{array}$ & $\begin{array}{l}-.3022 \\
p=.105\end{array}$ & $\begin{array}{c}-.1673 \\
p=.377\end{array}$ & $\begin{array}{c}.5002 \\
p=.005\end{array}$ & $\begin{array}{c}.4145 \\
p=.023\end{array}$ \\
\hline ER & $\begin{array}{l}-1.0000 \\
p=0.00\end{array}$ & $\begin{array}{c}1.0000 \\
p=-\end{array}$ & $\begin{array}{c}-.4999 \\
p=.005\end{array}$ & $\begin{array}{c}.7660 \\
p=.000\end{array}$ & $\begin{array}{c}.2548 \\
p=.174\end{array}$ & $\begin{array}{l}-.3015 \\
p=.105\end{array}$ & $\begin{array}{c}.3022 \\
p=.105\end{array}$ & $\begin{array}{c}.1673 \\
p=.377\end{array}$ & $\begin{array}{l}-.5002 \\
p=.005\end{array}$ & $\begin{array}{l}-.4145 \\
p=.023\end{array}$ \\
\hline IR & $\begin{array}{c}.4999 \\
p=.005\end{array}$ & $\begin{array}{c}-.4999 \\
p=.005\end{array}$ & $\begin{array}{c}1.0000 \\
p=-\end{array}$ & $\begin{array}{c}-.2108 \\
p=.263\end{array}$ & $\begin{array}{l}-.0653 \\
p=.732\end{array}$ & $\begin{array}{c}.2755 \\
p=.141\end{array}$ & $\begin{array}{c}-.1544 \\
p=.415\end{array}$ & $\begin{array}{c}-.0869 \\
p=.648\end{array}$ & $\begin{array}{c}1.0000 \\
p=0.00\end{array}$ & $\begin{array}{c}.1710 \\
p=.366\end{array}$ \\
\hline EDR & $\begin{array}{c}-.7660 \\
p=.000\end{array}$ & $\begin{array}{c}.7660 \\
p=.000\end{array}$ & $\begin{array}{l}-.2108 \\
p=.263\end{array}$ & $\begin{array}{c}1.0000 \\
p=-\end{array}$ & $\begin{array}{c}.1306 \\
p=.492\end{array}$ & $\begin{array}{l}-.2269 \\
\mathrm{p}=.228\end{array}$ & $\begin{array}{c}.1525 \\
p=.421\end{array}$ & $\begin{array}{c}.0565 \\
p=.767\end{array}$ & $\begin{array}{l}-.2110 \\
p=.263\end{array}$ & $\begin{array}{l}-.3397 \\
p=.066\end{array}$ \\
\hline ICR & $\begin{array}{l}-.2548 \\
p=.174\end{array}$ & $\begin{array}{c}.2548 \\
p=.174\end{array}$ & $\begin{array}{l}-.0653 \\
p=.732\end{array}$ & $\begin{array}{c}.1306 \\
p=.492\end{array}$ & $\begin{array}{c}1.0000 \\
p=-\end{array}$ & $\begin{array}{c}-.1597 \\
p=.399\end{array}$ & $\begin{array}{c}.0678 \\
p=.722\end{array}$ & $\begin{array}{c}.0235 \\
p=.902\end{array}$ & $\begin{array}{l}-.0654 \\
p=.731\end{array}$ & $\begin{array}{c}.0972 \\
p=.609\end{array}$ \\
\hline IE & $\begin{array}{c}.3015 \\
p=.105\end{array}$ & $\begin{array}{c}-.3015 \\
p=.105\end{array}$ & $\begin{array}{c}.2755 \\
p=.141\end{array}$ & $\begin{array}{c}-.2269 \\
p=.228\end{array}$ & $\begin{array}{c}-.1597 \\
p=.399\end{array}$ & $\begin{array}{c}1.0000 \\
p=-\end{array}$ & $\begin{array}{c}-.2415 \\
p=.199\end{array}$ & $\begin{array}{c}-.1927 \\
p=.308\end{array}$ & $\begin{array}{c}.2755 \\
p=.141\end{array}$ & $\begin{array}{c}-.3681 \\
p=.045\end{array}$ \\
\hline EFAR & $\begin{array}{l}-.3022 \\
p=.105\end{array}$ & $\begin{array}{c}.3022 \\
p=.105\end{array}$ & $\begin{array}{l}-.1544 \\
p=.415\end{array}$ & $\begin{array}{c}.1525 \\
p=.421\end{array}$ & $\begin{array}{c}.0678 \\
p=.722\end{array}$ & $\begin{array}{l}-.2415 \\
p=.199\end{array}$ & $\begin{array}{c}1.0000 \\
p=-\end{array}$ & $\begin{array}{c}.9871 \\
p=0.00\end{array}$ & $\begin{array}{c}-.1545 \\
p=.415\end{array}$ & $\begin{array}{c}.0441 \\
p=.817\end{array}$ \\
\hline LCFAR & $\begin{array}{c}-.1673 \\
p=.377\end{array}$ & $\begin{array}{c}.1673 \\
p=.377\end{array}$ & $\begin{array}{c}-.0869 \\
p=.648\end{array}$ & $\begin{array}{c}.0565 \\
p=.767\end{array}$ & $\begin{array}{c}.0235 \\
p=.902\end{array}$ & $\begin{array}{c}-.1927 \\
p=.308\end{array}$ & $\begin{array}{c}.9871 \\
p=0.00\end{array}$ & $\begin{array}{c}1.0000 \\
p=-\end{array}$ & $\begin{array}{c}-.0870 \\
p=.648\end{array}$ & $\begin{array}{c}.1247 \\
p=.512\end{array}$ \\
\hline $\mathrm{FL}$ & $\begin{array}{c}.5002 \\
p=.005\end{array}$ & $\begin{array}{l}-.5002 \\
p=.005\end{array}$ & $\begin{array}{c}1.0000 \\
p=0.00\end{array}$ & $\begin{array}{c}-.2110 \\
p=.263\end{array}$ & $\begin{array}{l}-.0654 \\
p=.731\end{array}$ & $\begin{array}{c}.2755 \\
p=.141\end{array}$ & $\begin{array}{c}-.1545 \\
p=.415\end{array}$ & $\begin{array}{c}-.0870 \\
p=.648\end{array}$ & $\begin{array}{c}1.0000 \\
p=-\end{array}$ & $\begin{array}{c}.1712 \\
p=.366\end{array}$ \\
\hline $\begin{array}{l}\text { EVA } \\
\text { ROS }\end{array}$ & $\begin{array}{c}.4145 \\
p=.023\end{array}$ & $\begin{array}{c}-.4145 \\
p=.023\end{array}$ & $\begin{array}{c}.1710 \\
p=.366\end{array}$ & $\begin{array}{c}-.3397 \\
p=.066\end{array}$ & $\begin{array}{c}.0972 \\
p=.609\end{array}$ & $\begin{array}{c}-.3681 \\
p=.045\end{array}$ & $\begin{array}{c}.0441 \\
p=.817\end{array}$ & $\begin{array}{c}.1247 \\
p=.512\end{array}$ & $\begin{array}{c}.1712 \\
p=.366\end{array}$ & $\begin{array}{c}1.0000 \\
p=-\end{array}$ \\
\hline
\end{tabular}

Note: E - Equity, D - Debt. 


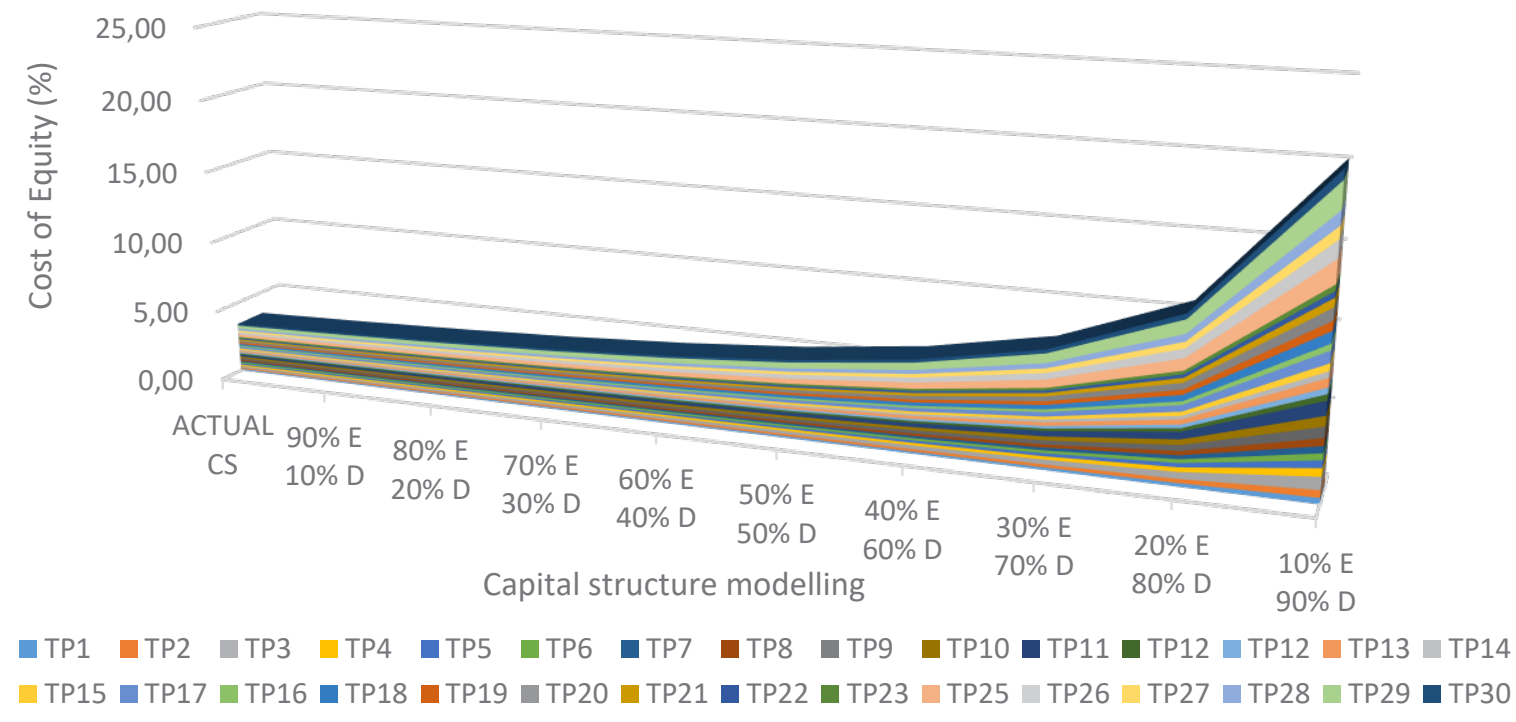

Figure 1. Development of the cost of equity following the change in capital structure

The cost of equity with the application of CAPM model was analyzed as the first value in our modelling of performance indicators in relation to changing capital structure. In the analysis, we did not include the company TP24 in the figure, as its capital structure was predominantly composed of debt, which, as a result, deformed the cost of equity curve. The same applied to companies TP25, TP26 and TP29. The company TP23 shows the minimum changes in the field of the cost of equity, because it mainly operates by using its equity. Consequently, it is possible to state that the companies, which use predominantly debt have higher cost of equity by further rise of their indebtedness. It proved the presupposition of the traditional approach that with increasing debt in capital structure, the cost of equity rises as a result of higher financial risk. Companies with dominant equity do not show significant increase in the Cost of Equity after the change of capital structure in favor of debt. In general, the cost of equity rises with the proportion of debt in capital structure, which is caused by the increase of systematic risk under the influence of rising indebtedness. At the same time, MM II proposition was proved. The rise of the cost of equity under the influence of the rising proportion of debt can be seen in Figure 1.

Next step was to analyze the weighted average capital cost. According to the MM theory, this cost is independent of capital structure because by increasing the debt, which has more financial benefits, the proportion of more expensive equity decreases. These two opposing effects are in balance. The weighted average capital cost according to the traditional approach of capital structure reaches the minimum value. It can be expected that in this case, it is when the capital structure is $80 \%$ of equity and $20 \%$ of debt, which means that the model respects the increasing financial risk arising from increasing indebtedness. However, it is possible to say that it is not a typical and significant U-curve, which is a precondition of validity of traditional approach (Figure 2).

We applied EVA equity and EVA entity indicators to analyze the impact of the change in capital structure on the performance. The results were different, which was caused by the way of calculation of these indicators. EVA equity value increases with rising indebtedness, which supports the proposition I of the modified MM theory. At the same time, the preconditions of some classic theories of capital structure were also fulfilled. However, it is necessary to point out that EVA equity takes into account only the application of equity. It means that with the increase in debt, the return on equity rises, while its value is higher than the financial risk following the increase in debt. The development of performance with the application of EVA equity 


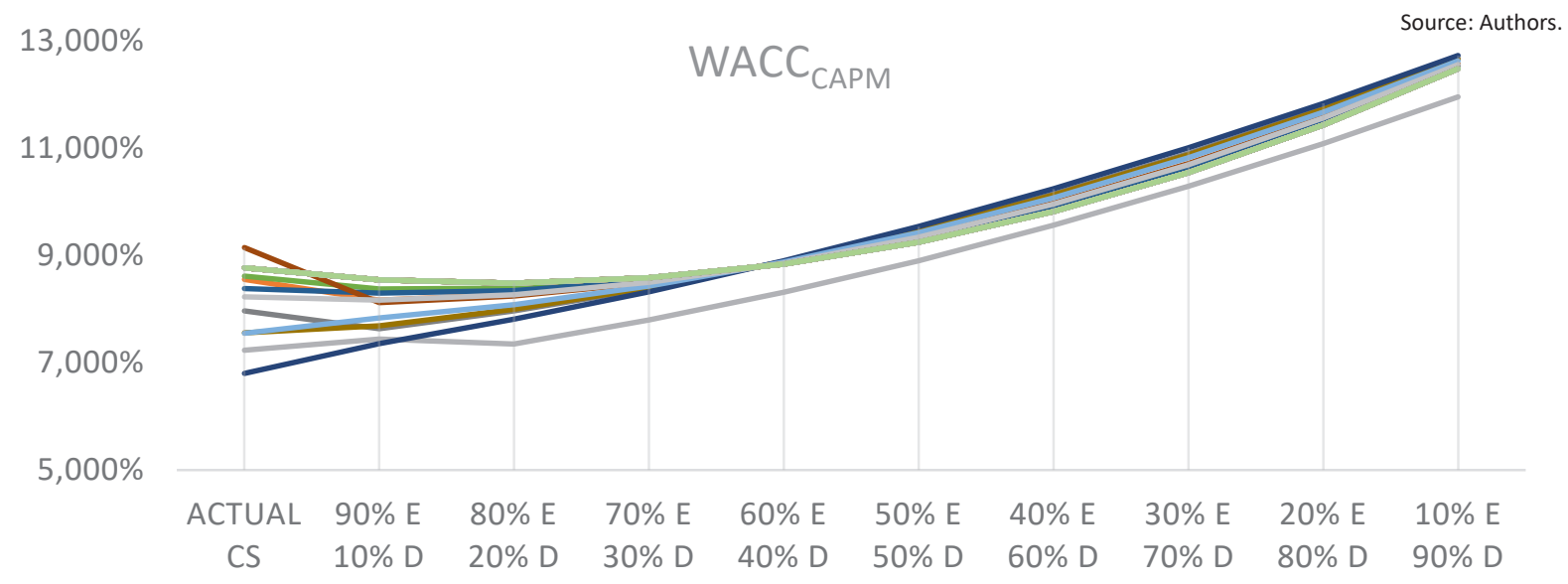

Capital structure modelling

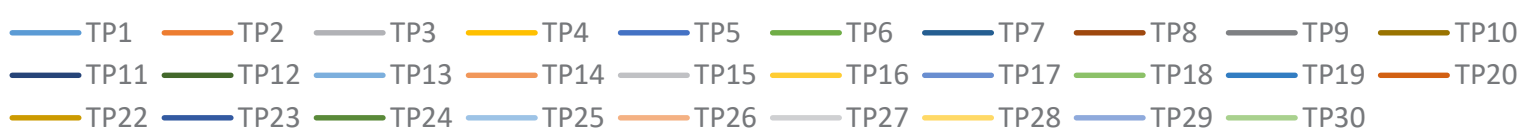

Figure 2. Development of weighted average capital cost following the change in capital structure

indicator can be seen in Figure 3. Unlike EVA equity indicator, the performance expressed by EVA entity indicator has its minimum which is reached when the capital structure is 90:10 in favor of equity. With the rise of debt, the performance increases. Based on this, it is possible to claim that the performance of a company rises with the increasing proportion of debt in the capital structure of the company. At the same time, we can state that this model takes into account the increasing financial risk of creditors, as well as owners.
Development of the EVA entity indicator can be seen in Figure 4.

As the last indicator, we analyzed a relative EVA - Spread. It is necessary not to include the company TP24 into analysis, because, as it was mentioned, this company predominantly operates on debt and further increase in debt is undesirable and causes significant decrease in its performance. Based on this analysis, we can state that by increasing the debt, the return on equity, as well as the cost of equity, also increase. It is ob-

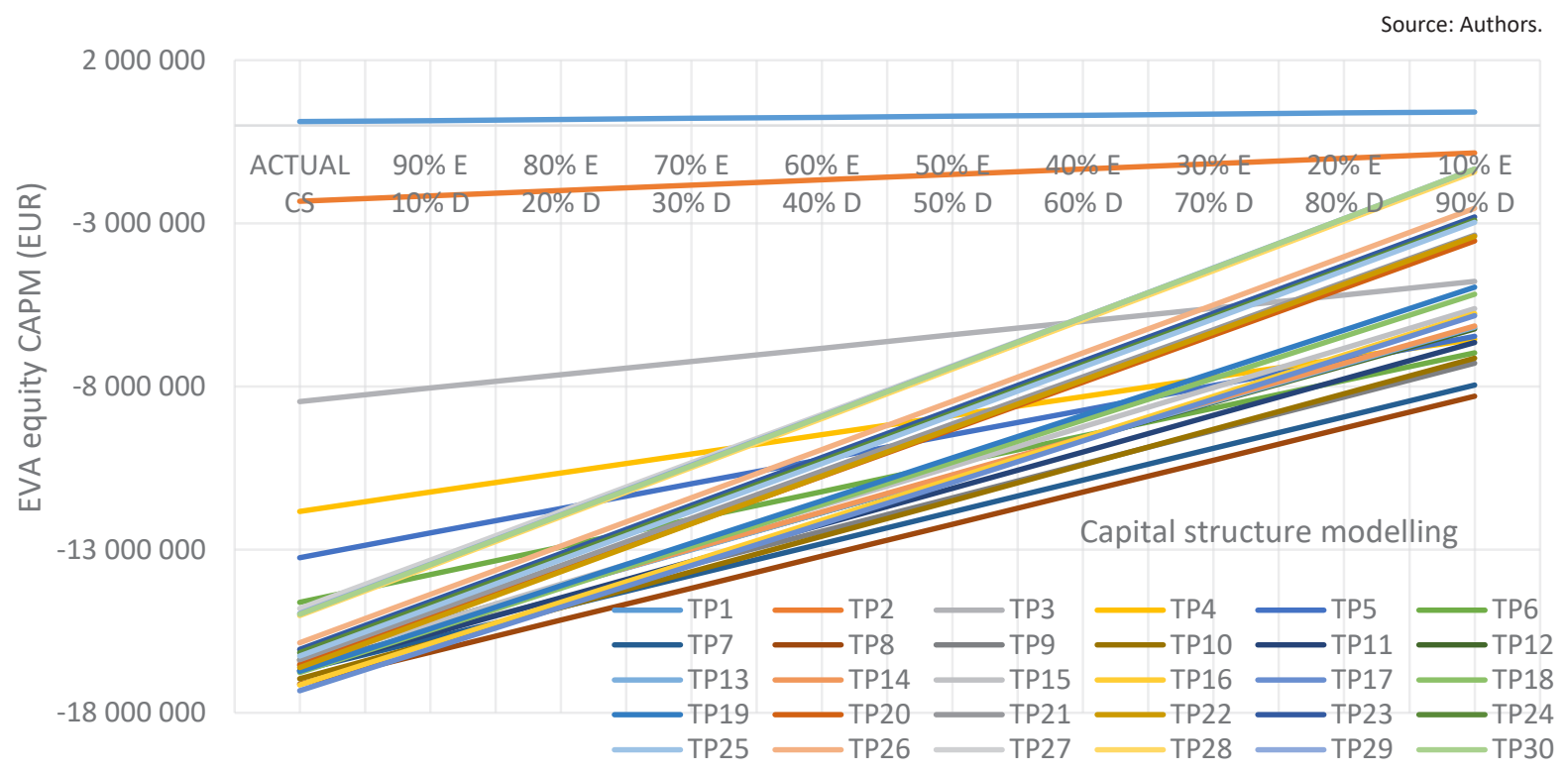

Figure 3. Development of the EVA equity indicator following the change in capital structure 


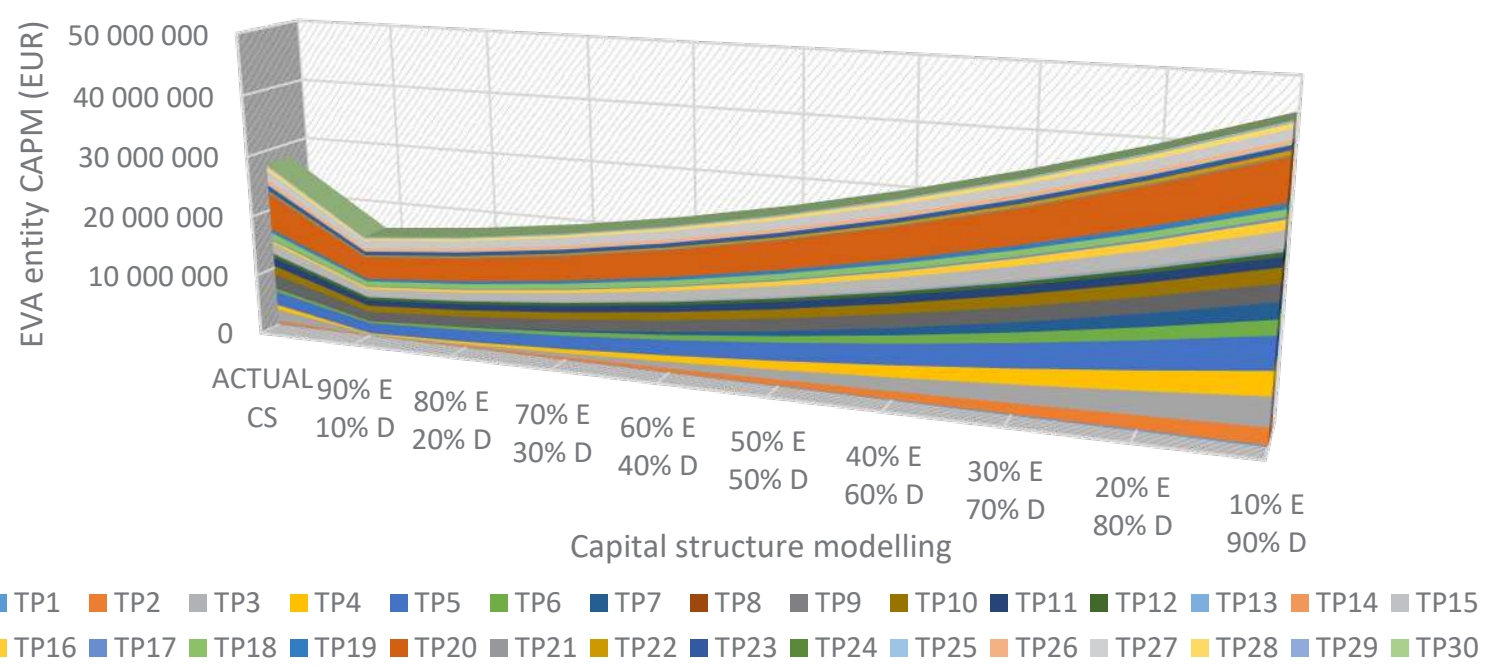

Figure 4. Development of the EVA entity indicator following the change in capital structure

vious from the results that the rise of the return is faster than the rise of the cost of equity. It follows then, that the relative EVA of the majority of analysed companies increases with the increase in debt. The development of Spread is illustrated in Figure 5.

In order to confirm Inka and Ivan Neumaier's view of the optimal capital structure, which is reached at the point with the highest return on equity, we constructed Figure 6, which shows the development of return on equity of the selected sample of businesses.

Based on the analysis of obtained data, we can say that in case of profit-making enterprises with a predominant share of equity, return on equity is rising by increasing the share of debt. In case of loss making enterprises, return on eqs uity decreases as a result of increase in debt.

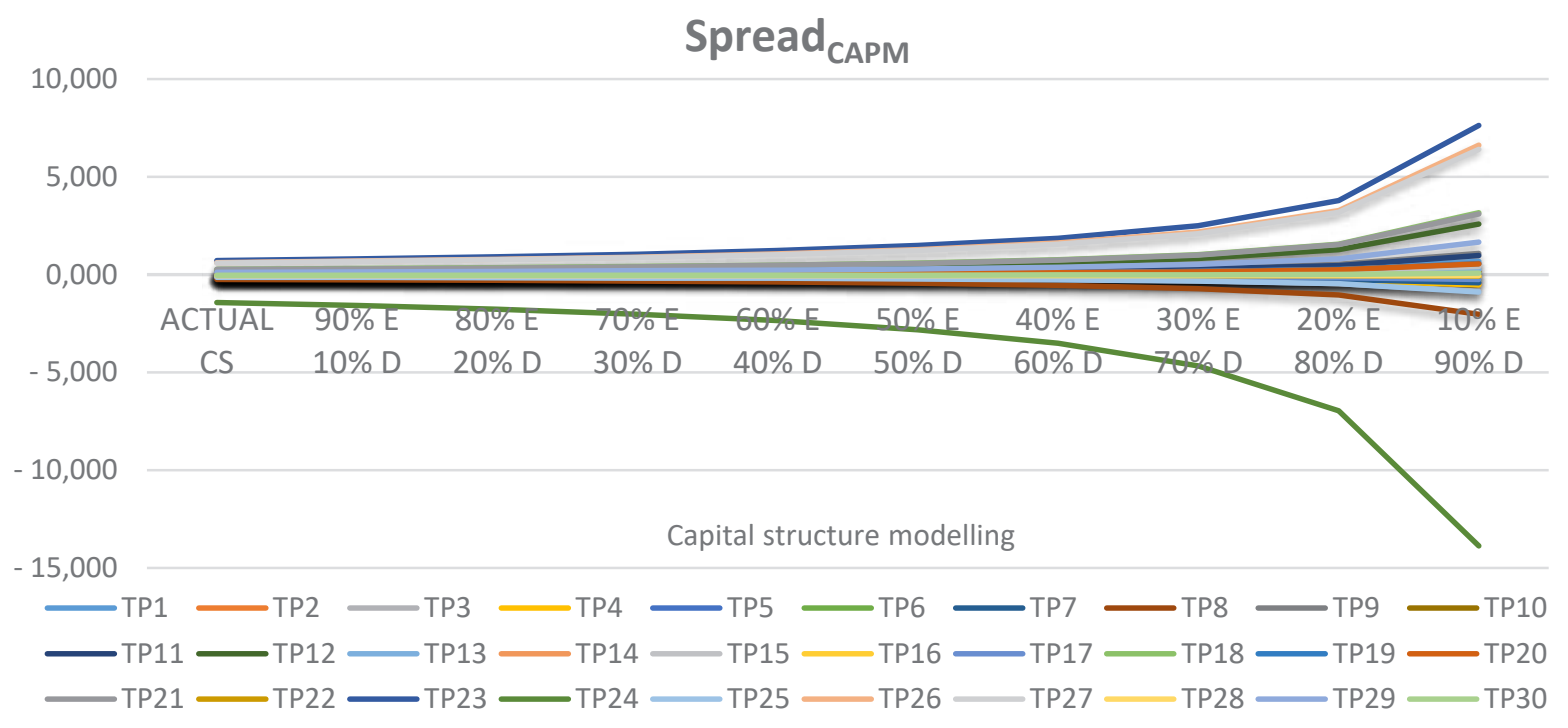

Figure 5. Development of spread following the change in capital structure 


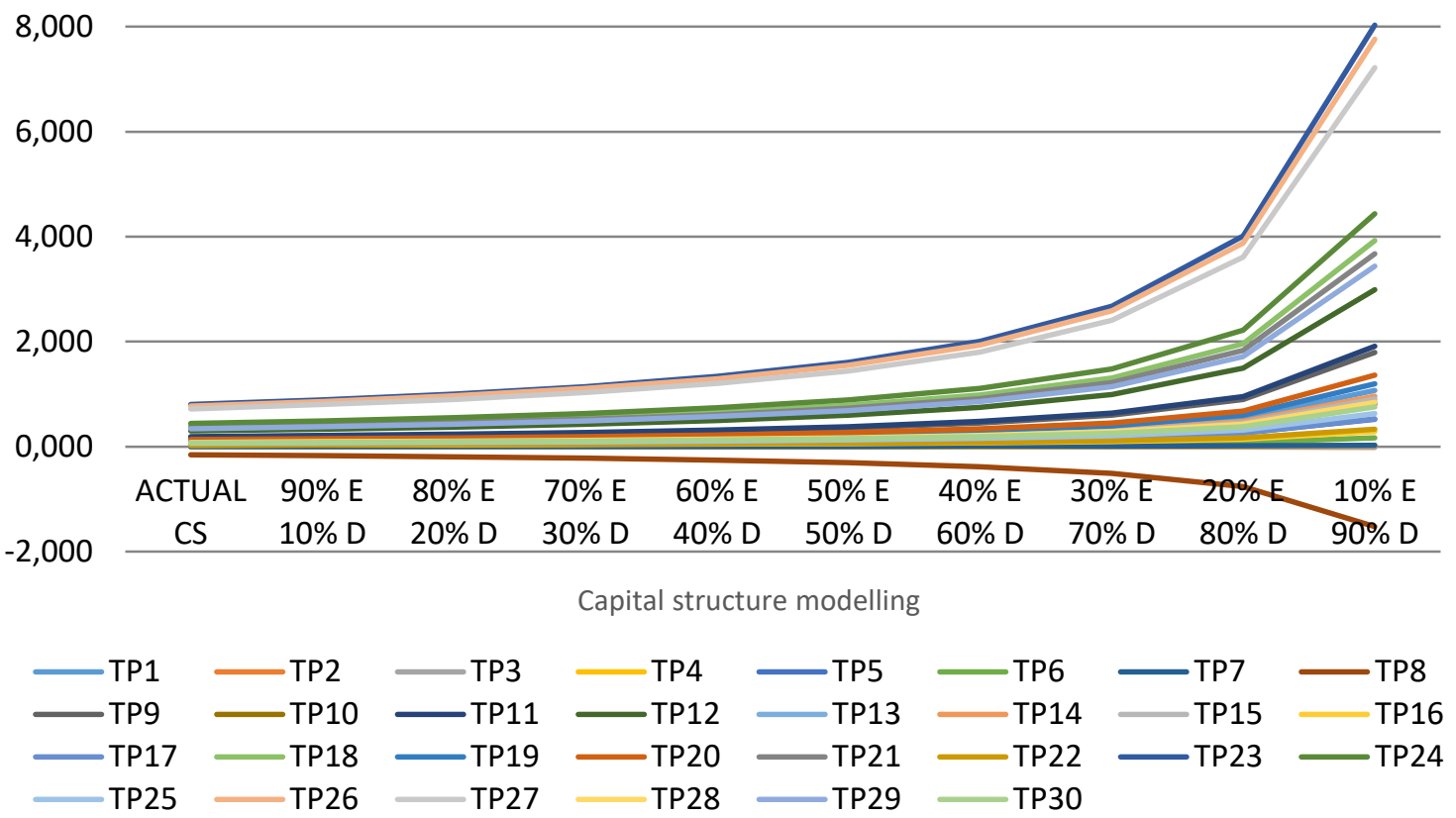

Figure 6. Development of return on equity

\section{CONCLUSION}

In the paper, we examined whether a change in the capital structure changes the performance of a company. With the use of correlation matrix, we found out that there is statistically significant relationship between the selected indicators of capital structure and performance. We confirmed directly proportional relationship between the performance and indicator debt ratio. We also confirmed indirectly proportional relationship between the performance and indicators equity ratio and interest expense. We were not able to apply multiple regression method due to the lack of data. Therefore, we analyzed the impact of capital structure on performance applying the method of modelling.

When modelling performance indicators depending on the change in capital structure, we used static and dynamic theories of capital structure optimization, and managed to prove several propositions of these models.

When modelling capital structure with the aim of its optimization, we changed the capital structure by gradual reduction of equity by $10 \%$ and at the same time by increasing the debt in the same proportion. Based on the realized analysis, we can generally say that with rising proportion of debt in the capital structure of companies, the return on equity, cost of equity, weighted average capital cost, as well as economic value added calculated by EVA entity and EVA equity methods, also increase. In most of the analyzed companies, the return on equity exceeds the cost of equity resulting in a positive value of the Spread indicator (relative EVA).

In terms of the research question and research objective, we also managed to find the optimal capital structure from the point of view of maximizing the performance and minimizing the cost of capital, which is $80 \%$ of equity and $20 \%$ of debt. At this composition of capital structure, the value of return on equity starts to rise.

In the future, we would like to expand our scientific work, especially in terms of creation of the necessary database. Using these data, we would be able to apply multiple regression by which we would identify the indicators of capital structure affecting business performance indicator. Using a sample of 
companies, our goal is to find out how company performance is influenced by capital structure. Based on these findings, we would like to provide the general basis of the optimization of capital structure for the businesses in Slovakia.

\section{ACKNOWLEDGEMENTS}

This paper was prepared within the grant scheme VEGA No 1/0887/17 - Increasing the competitiveness of Slovakia within the EU by improving efficiency and performance of production systems.

\section{REFERENCES}

1. AMO SR (2013). Functioning of heat energy sector in Slovakia focusing on DH systems from the AMO point of view. Retrieved from http://www.antimon.gov.sk/ data/att/1556.pdf

2. Bartošová, V. (2005). Optimalizácia finančnej štruktúry podniku [Optimization of Business Financial Structure]. Žilina: EDIS.

3. Bevan, A. A., \& Danbolt, J. (2002). Capital structure and its determinants in the UK - a decompositional analysis. Applied financial economics, 12(3), 159-170. https://doi. org/10.1080/09603100110090073

4. Cohen, J. (1998). Statistical power analysis for the behavioral sciences. Hillsdale, NJ: Lawrance Earlbaum Associates.

5. Damodaran, A. (2014). Equity Risk Premiums: Looking backwards and forwards... Retrieved from http:// people.stern.nyu.edu/adamodar/ pdfiles/country/ERP2014.pdf

6. EFQM (1999). Excellence Model. Retrieved from http:/www.efqm. org/award.htm

7. Fibírová, J., \& Šoljaková, L. (2005). Hodnotové nástroje řízení a měrení výkonnosti podniku [Value Tools to Manage and Measure Business Performance]. Praha: ASPI, a.s.

8. Frost, W. (2005). ABCs of Activity Based Management - Crushing Competition Through Performance Improvement. Bloomington: iUniverse LLC.

9. Gleason, K. C., Mathur, L. K., \& Mathur, I. (2000). The Interrelationship between
Culture, Capital Structure, and Performance: Evidence from European Retailers. Journal of Business Research, 50(2), 185-191. https://doi.org/10.1016/S01482963(99)00031-4

10. Harumová, A. et al. (2008). Stanovenie hodnoty majetku [Determination of the Value of the Assets]. Bratislava: Iura Edition.

11. Horváthová, J., \& Mokrišová, M. (2017). Capital Structure Modelling and Analysis of its Impact on Business Performance. Financial Assets and Investing, 8(2), 19-36. https://doi. org/10.5817/FAI2017-2-2

12. Hrdý, M., \& Horová, M. (2007). Aktuální problémy strategického finančního řízení podniků v ČR [Current Problems of Strategic Financial Management of Businesses in the Czech Republic]. E+M Ekonomie a Management, 10(4), 80-86. Retrieved from http://www. ekonomie-management.cz/ archiv/vyhledavani/detail/115aktualni-problemy-strategickehofinancniho-rizeni-podniku-v-cr/

13. Hudec, O. et al. (2007). Štatistické metódy v ekonomických vedách [Statistical Methods in Economic Sciences]. Košice: elfa, s.r.o.

14. Jánošová, V. (2008). Zdroje financovania podniku [Sources of Business Financing]. Bratislava: Ekonóm.

15. Johnson, G., \& Kevan, S. (2000). Cesty $k$ úspešnému podnikaniu [Ways to a Successful Business]. Praha: Computer Press.
16. Krishnan, M., \& Moyer, R. C. (1997). Performance, Capital Structure and Home Country: An Analysis of Asian Corporations. Global Finance Journal, 8(1), 129-143. https://doi.org/10.1016/ S1044-0283(97)90010-7

17. Mařík, M., \& Maříková, P. (2005). Moderni metody hodnoceni výkonnosti a oceňování podniku: ekonomická přidaná hodnota, tržní prridaná hodnota, CF ROI [Modern Methods of Business Performance Evaluation: Economic Value Added, Market Value Added, CF ROI]. Praha: Ekopress.

18. MHSR (2014). Návrh energetickej politiky Slovenskej republiky [Energy policy of the Slovak Republic]. Retrieved from http:// www.rokovania.sk/File.aspx/ViewDocumentHtml/Mater-Dokum168597? prefixFile $=\mathrm{m}_{-}$

19. Modigliani, F., \& Miller, K. H. (1958). The Cost of Capital, Corporation Finance and the Theory of Investment. American Economic Review, 48(3), 261-297.

20. Myers, S. C., \& Majluf, N. F. (1984). Corporate financing and investment decisions when firms hav e information that investors do not have. Journal of financial economics, 13(2), 187-221. https://doi.org/10.1016/0304405X(84)90023-0

21. Neumaierová, I., \& Neumaier, I. (1996). Úvaha o optimální zadluženosti [Determining the Optimal Level of Indebtedness]. Finance a úvěr, 46(1), 51-61. Retrieved from http://journal.fsv.cuni. cz/storage/2172_199601in.pdf 
22. Neumaierová, I., \& Neumaier, I. (2002). Výkonnost a tržní hodnota firmy [Performance and Market Value of a Company]. Praha: Grada Publishing.

23. RUZ (2017). Register účtovných závierok [Register of Financial Statements]. Retrieved from http:// www.registeruz.sk/cruz-public/ home/

24. Sedláček, J. (2009). Finanční analýza podniku [Financial Analysis of a Business]. Brno: Computer press, a. s.

25. Sedláček, M., Suchánek, P., \& Špalek, J. (2012). Kvalita a výkonnost prümyslových podniků [Quality and Performance of Industrial Businesses]. Brno: Masarykova univerzita.

26. Sivák, R., \& Mikócziová, J. (2009). Teória a politika kapitálovej štruktúry podnikatelských subjektov [Business Capital Structure Theory and Policy]. Bratislava: Sprint dva.

27. Sheik, N. A. (2013). The impact of capital structure on performance: An empirical study of nonfinancial listed firms in Pakistan. International Journal of Commerce and Management, 23(4), 354-368. https://doi.org/10.1108/IJCoMA-11-2011-0034

28. Souček, Z. (2010). Firma 21. stoleti: (Předstihnème nejlepší!!!) [Business of the 21st Century: (Let's Overtake the Best!!!)]. Praha: Professional Publishing.

29. Suchánek, P. et al. (2013). Vliv kvality na výkonnost a konkurenceschopnost podniku [The Impact of Quality on Business Performance and Competitiveness]. Brno: Masarykova univerzita.

30. Synek, M. et al. (2003). Manažerská ekonomika [Managerial Economics]. Praha: Grada Publishing.

31. Šulák, M., \& Vacík, E. (2005). Měřni výkonnosti firem [Measurement of Business Performance]. Plzeň. Západočeská univerzita.

32. Valach, J. (2001). Investiční rozhodování a dlouhodobé financování [Investment Decision Making and Long-term Financing]. Praha: EKOPRESS

33. Veber, J. (2004). Nové prístupy managementu - II. Část [New Management Approaches - 2nd part]. Ekonomika a management podniku, 2(2), 6-19.

34. Vlachynský, K. et al. (1999). Podnikové financie [Business Finance]. Bratislava: Vydavatelstvo Súvaha, spol. s.r.o.

35. Vlachynský, K. et al. (2002). Podnikové financie [Business Finance]. Bratislava: Súvaha.

36. Wagner, J. (2009). Měření výkonnosti [Performance Measurement]. Praha: GRADA Publishing.

37. Závarská, Z. (2012). Manažment kapitálovej štruktúry pri financovaní rozvoja podniku ako nástroj zvyšovania finančnej výkonnosti [Capital Structure Management in Financing the Development of a Business as a Tool for Increasing Financial Performance]. Prešov: Prešovská univerzita.

38. Zeitun, R., \& Tian, G. G. (2014). Capital structure and corporate performance: evidence from Jordan. Australasian Accounting Business \& Finance Journal, 1(3), 40-61. Retrieved from http:// ro.uow.edu.au/cgi/viewcontent. cgi article $=1018 \&$ context $=$ aabf 